\title{
Startup Reaktor Cepat Berpendingin Gas Berbahan Bakar UN-PuN dengan Daya 800 MWth
}

\author{
Tri Siswandi Syahputra-a*, Zaki Suud-b \\ aProgram Studi Fisika, Jurusan Sains Institut Teknologi Sumatera, bInstitut Teknologi Bandung, \\ Jalan Terusan Ryacudu, Way Hui, Lampung Selatan, Indonesia \\ *email : trisiswandi@itera.ac.id
}

\begin{abstract}
Abstrak
Studi startup reaktor cepat berpendingin helium dengan bahan bakar uranium alam dan spent fuel dari PWR telah dilakukan. Reaktor dengan keluaran daya menengah dioperasikan dengan pengisian ulang bahan bakar setiap 5 tahun selama 40 tahun beroperasi. Perhitungan neutronik dilakukan dengan menggunakan sistem pengkodean SRAC dan JENDL -33 library, dengan model teras cylindrical cell 2D R-Z. Reaktor didesain dengan strategi startup pembakaran CANDLE (Constan Axial shape of Neutron flux, nuclide densities and power shape During Life of Energy producing reactor) yang dimodifikasi dari keadaan awal sampai akhir operasi. Dalam skema ini, teras aktif dibagi menjadi region-1 sampai dengan region-10 arah aksial dengan volume yang sama dan 2 region arah radial dengan fuel fraction berbeda. Bahan bakar fresh Uranium alam awalnya dimasukkan ke dalam region- 1, sedangkan region lainnya diisi oleh campuran uranium alam dan spent fuel dari PWR. Setelah satu siklus operasi, dilakukan pergeseran region-1 ke region-2, region-2 ke region -3 dan seterusnya. Bahan bakar pada region -10 dibuang sedangkan region-1 akan diisi kembali oleh bahan bakar Uranium alam. Ukuran daya reaktor 800 MWth dengan variasi fraksi bahan bakar telah diselidiki. Perhitungan dilakukan terhadap desain teras reaktor yang menggunakan variasi fraksi bahan bakar di bagian dalam dan luar : 50\%,55\%; 55\%,60\%, dan 60\%,65\%. Reaktor dengan fraksi bahan bakar 50,55\% menunjukan desain yang optimal dengan rasio antara puncak dengan daya ratarata diperoleh nilai 1.57 arah radial dan 2.57 arah aksial.
\end{abstract}

Kata Kunci : Reaktor Cepat, Modified CANDLE, Spent fuel

\section{Latar Belakang}

Perkembangan reaktor nuklir mengalami perubahan fase dari generasi I sampai ke generasi IV. Sistem reaktor nuklir generasi IV adalah sistem teknologi yang berkompetisi di semua pasar dengan teknologi paling efektif dan memiliki kelebihan mengembangkan sistem keselamatan pasif yang mampu meminimalkan kecelakaan. Salah satu jenis reaktor generasi IV adalah Gas-Cooled Fast Reactor (GFR). GFR dipertimbangkan sebagai konsep yang memiliki prospek cerah dan memiliki prioritas tinggi dalam pembangunan sistem energi nuklir dilengkapi dengan fitur utama terkait keberlanjutan, ketahanan daur ulang, ekonomis dan faktor keselamatan.[1].

Reaktor yang memiliki level burnup tinggi akan lebih menjanjikan dari segi ekonomi dan fleksibilitas. Saat ini terdapat beberapa metode peningkatan level burnup diantaranya adalah CANDLE (Constant Axial shape of Neutron flux, nuclide densities, and power shape During Life of Energy production). Metode ini membagi bahan bakar menjadi beberapa region, proses pembakaran seperti pembakaran pada lilin. Metode ini menghasilkan burnup yang tinggi namun kurang fleksibel dalam pergantian bahan bakar[2].

Untuk meningkatkan fleksibilitas, dilakukan modifikasi metode tersebut dengan cara membagi teras arah aksial menjadi beberapa region dengan volume sama namun berisikan bahan bakar yang berbeda (gambar 1). Setelah satu periode operasi, dilakukan proses pemindahan bahan bakar ditiap region. Metode ini menghasilkan burnup dan faktor multifikasi efektif yang tinggi, namun hanya menyajikan data neutronik selama satu periode pengisian bahan bakar[3.4].

Diperlukan proses startup yaitu suatu konsep analisis reaktor yang dapat menghitung faktor multifikasi dari awal operasi sampai berakhir operasi dengan metode CANDLE yang dimodifikasi dengan input bahan bakar Uraniun alam dan spent fuel dari reaktor termal (PWR). Desain dioptimasi dengan memvariasikan fraksi bahan bakar pada arah aksial dan radial.

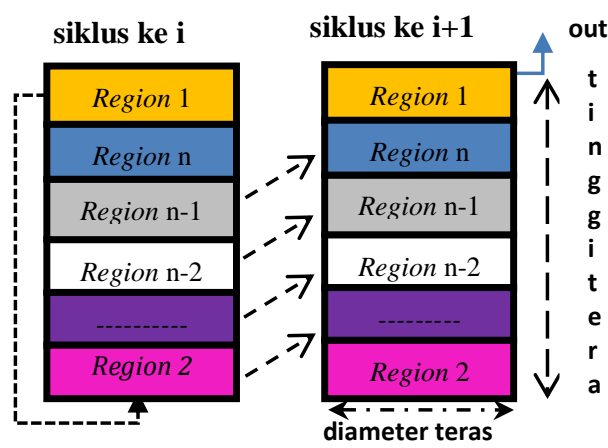

Gambar 1. Pembagian region dan pemindahan bahan bakar Modified Candle 


\section{Metodologi}

Penelitian ini dilaksanakan dengan menggunakan program SRAC (Standard Thermal Reactor Analysis Code System) yang dikembangkan JAERI Uapan Atomic Energy Research Institute) dengan menggunakan data nuklir versi JENDL-33 library. Spesifikasi umum reaktor yang diterapkan pada simulasi analisis neutronik seperti terlihat pada Tabel 1 .

Tabel 1. Spesifikasi umum desain reaktor.

\begin{tabular}{ll}
\hline \multicolumn{1}{c}{ Parameter } & \multicolumn{1}{c}{ Spesifikasi } \\
\hline Daya termal & 800 MWth \\
Periode Burnup & 40 tahun \\
Periode Refueling & 5 tahun \\
Geometri Teras & Cylinder Balance \\
Bahan Bakar & UnPuN \\
Cladding & SS316 \\
Coolant & Helium \\
Tipe Pin cell & Cylinder cell \\
Pin pitch/diameter & $1.45 \mathrm{~cm}$ \\
Tinggi Teras aktif & $240 \mathrm{~cm}$ \\
Diameter Teras Aktif & $180 \mathrm{~cm}$ \\
Tebal Cladding & $10 \mathrm{~mm}$ \\
Tebal Reflektor & $65 \mathrm{~cm}$ \\
\hline
\end{tabular}

Perhitungan ini menggunakan geometri PIJ (modul untuk menghitung neutronik tingkat sel bahan bakar) dengan metode matriks probabilitas tumbukan sebagai langkah awal analisis perancangan reaktor nuklir. Sel silinder berukuran $1.45 \mathrm{~cm}$ satu dimensi yang dibagi 3 daerah yaitu : daerah pertama adalah bahan bakar (fuel) dengan jari jari $0.55 \mathrm{~cm}$, daerah kedua adalah kelongsong (cladding) dengan tebal $0.04 \mathrm{~cm}$ dan daerah ketiga adalah pendingin (coolant) dengan tebal $0.135 \mathrm{~cm}$. Sedangkan geometri teras pada tabel 1 digambarkan pada gambar 2 berikut :

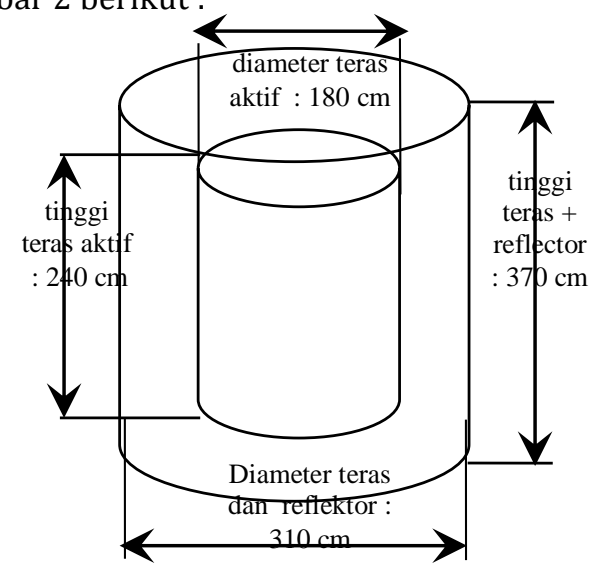

Gambar 2. Geometri teras reaktor

Dalam perhitungan Teras, CITATION (modul untuk menyelesaikan persamaan difusi multigrup) pada SRAC diambil bagian $1 / 2$ teras. Desain teras heterogen dibagi menjadi 10 daerah aksial dan 2 daerah radial (inner dan outer) dengan mengatur komposisi bahan bakar pada arah aksial dan radial sehingga seperti pada Gambar 3:

\begin{tabular}{|c|c|c|c|c|}
\hline $\mathrm{R}$ & $\mathrm{R}$ & $\mathrm{R}$ & & \multirow{2}{*}{$\begin{array}{l}\text { Kompoisisi bahan } \\
\text { Uranium Alam }\end{array}$} \\
\hline $\mathrm{F} 1$ & $\mathrm{~F} 1 "$ & $\mathrm{R}$ & & \\
\hline F10 & F10" & $\mathrm{R}$ & $\rightarrow$ & $13 \%$ Spent fuel \\
\hline F9 & F9" & $\mathrm{R}$ & $\rightarrow$ & $\begin{array}{l}\text { Uranium Alam + } \\
12 \% \text { Spent fuel }\end{array}$ \\
\hline F8 & F8" & $\mathrm{R}$ & $\rightarrow$ & $\begin{array}{l}\text { Uranium Alam }+11 \% \\
\text { Spent fuel }\end{array}$ \\
\hline F7 & F7" & $\mathrm{R}$ & $\rightarrow$ & $\begin{array}{l}\text { Uranium Alam }+10 \% \\
\text { Spent fuel }\end{array}$ \\
\hline F6 & F6" & $\mathrm{R}$ & $\rightarrow$ & $\begin{array}{l}\text { Uranium Alam + 9\% } \\
\text { Spent fuel }\end{array}$ \\
\hline F5 & F5" & $\mathrm{R}$ & $\rightarrow$ & $\begin{array}{l}\text { Uranium Alam + 8\% } \\
\text { Spent fuel }\end{array}$ \\
\hline $\mathrm{F} 4$ & F4" & $\mathrm{R}$ & $\rightarrow$ & $\begin{array}{l}\text { Uranium Alam + 7\% } \\
\text { Spent fuel }\end{array}$ \\
\hline F3 & F3" & $\mathrm{R}$ & $\rightarrow$ & $\begin{array}{l}\text { Uranium Alam + 6\% } \\
\text { Spent fuel }\end{array}$ \\
\hline $\mathrm{F} 2$ & $\mathrm{~F} 2 ”$ & $\mathrm{R}$ & $\rightarrow$ & $\begin{array}{l}\text { Uranium Alam + 5\% } \\
\text { Spent fuel }\end{array}$ \\
\hline $\mathrm{R}$ & $\mathrm{R}$ & $\mathrm{R}$ & & \\
\hline & F1" & . & & $\begin{array}{l}\text { aksi rendah) } \\
\text { raksi tinggi) }\end{array}$ \\
\hline
\end{tabular}

Gambar 3. Ilustrasi sebuah teras dan pembagian bahan bakar

Startup dilakukan dengan menghitung aktivitas neutronik sepanjang tahun dan saat refueling dengan cara menggeser bahan bakar di region atas ke region 2, mengikuti region lain bergeser satu tahap. Sedangkan region 10 dibuang dan diganti dengan bahan bakar uranium alam, seperti ilustrasi pada gambar 1 .

Untuk mengetahui efektivitas burnup, divariasikan nilai fraksi bahan bakar region dalam dan luar yaitu : $50 \%$ dan 55\% ; 55\% dan $60 \%$ serta $60 \%$ dan $65 \%$.

Untuk optimalisasi nilai kritis, divariasikan komposisi spent fuel pada setiap region dengan komposisi $1-17 \%$ pada setiap region.

\section{Hasil dan Pembahasan}

Pada perhitungan sel (PIJ), bahan bakar diproses selama 40 tahun dengan interval pengambilan data (refueling) setiap 5 tahun sekali. Perhitungan sel bahan bakar tersebut menghasilkan beberapa parameter neutronik, diantaranya level burnup, faktor multiplikasi tak hingga ( $k$-inf), faktor multiplikasi efektif ( $k$-eff), dan distribusi daya. Selanjutnya nilai multiplikasi efektif dibandingkan dengan penambahan spent fuel dari PWR untuk mengurangi excess reactivity diawal periode operasi.

Perbandingan level burnup dengan fraksi bahan bakar antara 50;55\%, 55;60\% dan 60;65\% ditampilkan pada gambar 4 : 


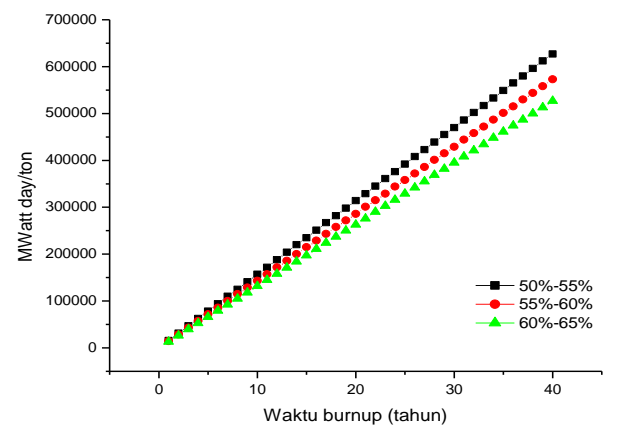

Gambar 4. Perubahan level burnup pada setiap fraksi bahan bakar

Pada gambar 4, terlihat bahwa fraksi bahan bakar yang lebih rendah berada pada level burnup lebih tinggi. Uranium pada fraksi terendah menghasilkan bahan bakar fisil lebih cepat dibandingkan dengan fraksi yang lebih tinggi, sehingga memiliki level burnup tertinggi. Semakin tinggi level burnup suatu reaktor maka efisiensi bahan bakar semakin baik dan akan menguntungkan dari segi ekonomi.

Perbandingan nilai faktor multifikasi tak hingga dengan fraksi bahan bakar antara 50;55\%, 55;60\% dan 60;65\% ditampilkan pada gambar 5 .

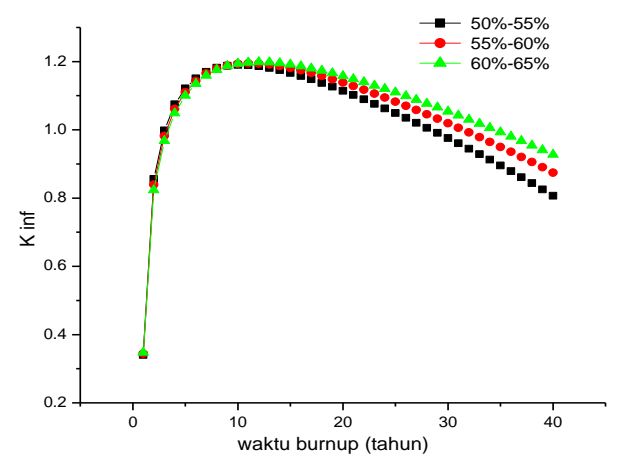

Gambar 5. Faktor multipikasi tak hingga reaktor terhadap periode burnup

Dari grafik pada gambar 5 terlihat bahwa semakin besar fraksi bahan bakar yang digunakan, maka semakin besar nilai k-inf yang bertahan sampai akhir periode umur reaktor, hal ini diakibatkan karna fraksi bahan bakar yang besar membuat banyak reaksi fisi sehingga jumlah neutron yang dihasilkan semakin besar seiring dengan besarnya jumlah flux neutron.

Hasil perhitungan teras reaktor juga menghasilkan Faktor multiplikasi efektif (k-eff) dan distribusi daya pada arah radial dan aksial. Perbandingan nilai k-eff pada daya 800 MWth dengan fraksi bahan bakar antara 50;55\%, $55 ; 60 \%$ dan $60 ; 65 \%$ ditampilkan pada gambar 6 .

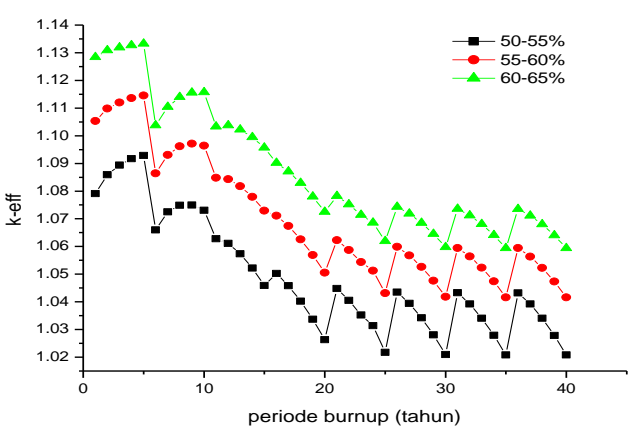

Gambar 6. Faktor multipikasi efektif setiap fraksi bahan bakar terhadap periode burnup

Pada Gambar 6 terlihat nilai k-eff selama 40 tahun dalam berbagai fraksi bahan bakar. Nilai k-eff diperoleh berkisar diatas 1 yang menunjukan reaktor dalam keadaan kritis, dan memungkinkan keberlangsungan reaksi fisi berantai. Fluktuasi nilai kekritisan reaktor merupakan akibat dari perbedaan jumlah bahan bakar fisil yang digunakan. Pada awal operasi terdapat banyak bahan bakar fisil yang terbiakkan dan mengalami reaksi fisi berantai pada teras aktif. [5]

Nilai k-eff diawal cukup tinggi, kemudian mengalami penurunan perlahan setelah tahun ke 10 , lalu sekitar tahun ke $15 \mathrm{k}$-eff mengalami pola berulang (fluktuasi) mendekati keadaaan keseimbangan. Hal ini dikarenakan setiap pergantian bahan bakar pada region 1 yang diisi oleh uranium alam, k-eff mengalami kenaikan sedikit, lalu kemudian turun kembali sampai periode refueling selanjutnya, begitu seterusnya sampai sampai 40 tahun. Saat refueling, k-eff mengalami kenaikan dikarenakan teras diisi bahan bakar yang baru sementara bahan bakar pada region 1 dibuang, akibatnya proses fisi yang dihasilkan akan semakin besar.

Semakin besar fraksi bahan bakar, maka semakin besar nilai k-eff yang dihasilkan. Ini dikarenakan fraksi bahan bakar yang besar mengandung material fisil yang lebih banyak yang dapat menghasilan banyak neutron yang baru. Dengan mempertimbangakan faktor excess reactivity dan keseimbangan $\mathrm{K}$-eff, desain reaktor dengan daya 800 MWth pada fraksi bahan bakar 50;55\% dipertimbangkan menjadi desain yang paling baik.

Variasi komposisi bahan bakar yang berbeda juga mempengaruhi keadaan kritis reaktor. Telah dilakukan beberapa variasi bahan bakar pada fraksi bahan bakar 50\%;55\% dengan menambahkan spent fuel dari PWR sebanyak 1$10 \%$ dan 3-17 \% masing masing pada region 210. Hasilnya ditunjukan pada gambar 7 . Penggunaan nilai komosisi spent fuel terhadap uranium alam yang besar (3-17\%) dengan tidak 
memperhatikan parameter lain mengakibatkan nilai k-eff dalam keadaan super kritis, sedangkan nilai komposisi spent fuel 1-10 \% menghasilkan nilai k-eff yang kritis dan ideal untuk dijadikan referensi pembagian bahan bakar. Hal ini dikarenakan spent fuel pada bahan bakar akan mempengaruhi populasi neutron diawal periode.

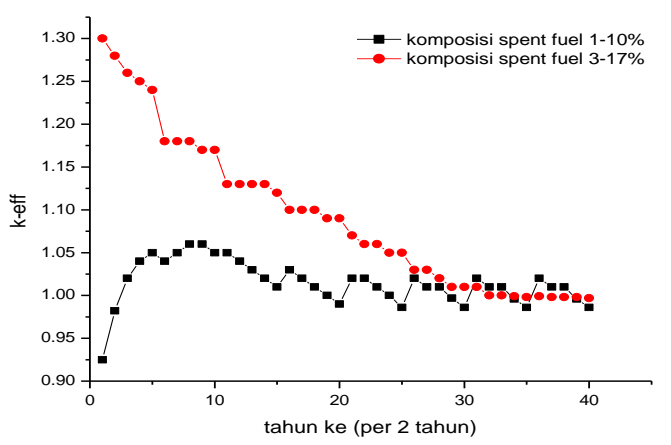

Gambar 7. Nilai k-eff pada komposisi spent fuel yang berbeda dengan daya keluaran 800 MWth

Distribusi daya arah radial dan aksial sangat diperlukan untuk mengetahui sebaran daya pada teras reaktor keseluruhan. Desain teras reaktor yang optimum memiliki distribusi daya yang merata. Distribusi daya yang merata dapat mengoptimasi reaktor dari aspek analisis termal hidrolik maupun aspek keamanan reaktor. Gambar 8 menunjukkan pola distribusi densitas daya di teras arah radial dan gambar 9 menunjukan pola distribusi densitas daya arah aksial pada awal, tengah dan akhir operasi reaktor.

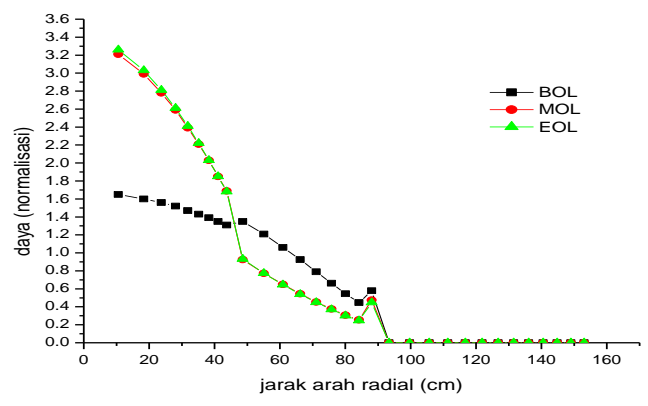

Gambar 8. Distribusi daya arah radial

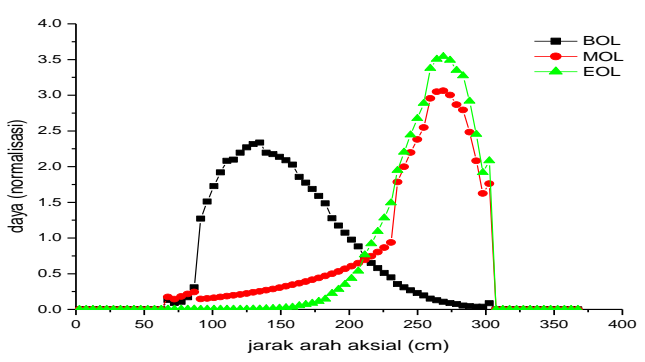

Gambar 9. Distribusi daya arah radial
Distribusi daya arah radial pada awal operasi (BOL) tengah operasi (MOL) dan akhir operasi (EOL) mengalami perbedan yang cukup signifikan. Perbedaan ini menunjukan bahwa distribusi daya akibat proses burnup berlangsung tidak merata. Kondisi ideal akan dicapai jika rasio antara puncak daya dengan daya rata-rata bernilai $\approx 1$ (power peaking). Pada perhitungan rasio antara puncak dengan daya rata-rata diperoleh nilai 1.57 awal operasi dan 1.7 untuk akhir operasi. Perbedaan kecepatan pembakaran yang terjadi di wilayah teras bagian dalam dengan teras bagian luar menyebabkan densitas daya tidak merata.

Variasi daya keluaran juga menunjukan bahwa semakin besar daya keluaran, maka semakin besar perubahan distribusi daya yang dihasilkan. Pada perhitungan, rasio antara puncak dengan daya rata-rata diperoleh nilai 2.57 dengan densitas daya $280 \mathrm{~W} / \mathrm{cc}$. Perbedaan kecepatan pembakaran yang terjadi di wilayah teras bagian dalam dengan teras bagian luar menyebabkan densitas daya tidak merata.

\section{Kesimpulan}

Desain reaktor yang dirancang menunjukan nilai faktor multiplikasi efektif yang kritis dan dapat dioperasikan dalam waktu 40 tahun. Pola k-eff yang berfluktuasi diakibatkan pengaruh perubahan burnup disetiap refueling dalam periode operasi dan membentuk keadaan keseimbangan pada 15 tahun.

Distribusi daya arah aksial dan radial mengalami pergeseran mulai dari awal operasi sampai akhir operasi. Nilai rasio antara puncak dengan daya rata-rata arah radial 1,7 pada Densitas daya $280 \mathrm{~W} / \mathrm{cc}$ dan 2.57 pada arah aksial dengan densitas daya $300 \mathrm{~W} / \mathrm{cc}$. Nilai ini masih normal dalam desain reaktor cepat. Sehingga melalui pertimbangan beberapa parameter neutronik, reaktor dengan daya 800 MWth dengan fraksi bahan bakar 50;55\% merupakan desain yang paling optimal.

\section{Daftar Pustaka}

[1] P. Dumaz, dkk. Gas-cooled fast reactors-Status of CEA preliminary design studies. Nuclera Enginering Design (2007).

[2] Sekimoto, Light a CANDLE, an Innovation Burnup Strategy of Nuclear Reactor, Second Edition. Tokyo Institute Of Technology JAPAN (2010)

[3] Menik Ariani, Desain Konseptual Reaktor Cepat Berpendingin Helium Dengan Skema Modified Candle Burnup Menggunakan Uranium/Thorium Alam Sebagai Input Siklus Bahan Bakar. Program Studi Fisika ITB (2007) 
POSITRON, Vol. VII, No. 1 (2017), Hal. 12 - 16

ISSN: 2301-4970 ( print )

http://dx.doi.org/10.26418/positron.v7i1.20809

ISSN: 2549-936X (online)

[4] Su'ud, Z., Sekimoto, H., Design Study of MediumSized Pb-Bi Cooled Fast Reactor with Natural Uranium as Fuel Cycle Input using Modified CANDLE Burnup Scheme, Int. J. NEST, Vol. 7, No. 1, 2012.

[5] M.K. Saadi, A. Abbaspour and A. Pazirandeh: Startup of “CANDLE”burnup in a Gas-cooled Fast Reactor using Monte Carlo method Annals of Nuclear Energy 50 pp p.44-49(2012) 